\title{
Right to access to environmental information in the Polish environmental protection law
}

\section{Introduction}

Environmental protection is a task to a realisation of which cooperation of the whole international community is essential. In a state the task lies above with public authorities - national and local, who are obliged to ensure environmental protection by means of implementation of legal regulations and direct activities (organizational and protective) based on them. However, the activity of public authorities only will not ensure efficient environmental protection in this field unless the community is sufficiently aware of the problem of environmental care and environmental. Historically, the concern of several countries at the end of 1960s at the size of negative impact of a man on environment due to progressing industrialization, gave the impulse to undertake international cooperation in this field. One of the first

* Doctor of Laws, The Environmental Law Protection Department of Nicolaus Copernicus University in Torun. 
results of social pressure exerted on public authorities of many countries, was the conference on human environment organised in 1972 in Stockholm under the auspices of the UN - United Nations Conference on the Human Environment and the implementation of the United Nations Environmental Programme (UNEP).

Twenty years after the conference in Stockholm another UN conference was held, which was essential for international cooperation for environmental protection and at the same time for the international law of environmental protection. The conference and its sessions were held in Rio de Janeiro between 3-14 June 1992 under the slogan 'Environment and Development'. The conference finished with the implementation of a declaration (soft law act), in which the basic rules of international cooperation in environmental protection were included. The declaration of Rio de Janeiro also mentions issues of public participation in environmental protection. In accordance with principle 10 of the Declaration: Environmental issues are best handled with participation of all concerned citizens, at the relevant level. At the national level, each individual shall have appropriate access to information concerning the environment that is held by public authorities, including information on hazardous materials and activities in their communities, and the opportunity to participate in decision-making processes. States shall facilitate and encourage public awareness and participation by making information widely available. Effective access to judicial and administrative proceedings, including redress and remedy, shall be provided.

Analysing principle 10 of the Declaration of Rio de Janeiro one might indicate that public participation in environmental protection, i.e. including members of the society in issues concerning environment and its protection, should in the first place mean informing the society how the task of environmental care and protection is conducted by public authorities (especially including administrative law restrictions of human activities causing danger for environment, e.g. by using hazardous substances). A member of a society of a given state was equipped thus with the right to access to information on environment and its protection from the public authorities. The Declaration of Rio specifically defines a state as a level of realisation of that right, expressed within international cooperation concerning environment. In principle 10 another instrument of public 
Right to access to environmental information in the Polish environmental...

participation in environmental matters is indicated (rather laconically) i.e. public participation in decision-making by public authorities in matters concerning environment. The recommendation resulting from principle 10 of the Declaration of Rio saying that states should strive to ensure public those two rights - access to environmental information and participation in decision-making concerning environment - was provided with an additional stipulation. In accordance with the stipulation, states should simultaneously provide the entitled person with law protection in case their rights within public participation in environmental matters are breached. The aim of the stipulation is to make the execution of those two rights more realistic in a given state by giving trial rights (e.g. an appeal against an administrative decision refusing access to requested environmental information).

Poland participated actively in the conference in Rio de Janeiro. Although the Declaration of Rio de Janeiro is only a non-binding legal act (soft law), after 1992 the Polish state began unilaterally the realisation of many of its resolutions, including principle 10 of the Declaration. Significant is the fact that, the Polish legislator directly indicated in article 5 of the new Constitution of the Republic of Poland of 2 April $1997^{2}$ that the Polish state ensures environmental protection, following the rule of sustainable development. The issue of social participation was mentioned in article 74 section 3 and 4 of the Constitution of 1997, stating that everybody has the right to information about the condition and protection of environment, whereas public authorities support citizens' activities for protection and improvement of environmental condition.

Regulations of the constitution have by nature the character of general norms, specified then in ordinary normative acts - in Poland in acts and executive acts issued on the grounds of legislative authorisation, i.e. directives and local law acts. Issues concerning both rules of public participation in environmental matters and environmental protection were not enclosed in the act of 31 January 1980 on environmental protection and its development ${ }^{3}$. The Polish legislator originally chose the model

2 Journal of Laws of 1997 , No 78, item 483 with amendments.

3 I.e. Journal of Laws of 1994, No 49, item 196 with amendments, repealed on the grounds of Art. 2 item 3 of the act of 27 June 2001 on implementing the act - the Environmental Protection Act, the act on waste management and on amendments to some laws, Journal of Laws of 2001, No 100, item 1085. 
of implementing those matters into the Polish environmental protection law outside the main act for this law branch. It was the act of 9 November 2000 on access to information on environment and its protection and on environmental impact assessment ${ }^{4}$ (in force since 1 October 2001). Then the regulations concerning those two rules were enclosed into the new main act, i.e. the act of 27 April 2001 the Environmental Protection Act (further referred to as the EPA) 5 . In 2008 the Polish legislator decided that those regulations should be transferred from the main act - the EPA into the new act. The transformation should be assessed negatively, as it disperses legal regulations, which can make difficult to apply those regulations by authorised bodies and administrative bodies obliged to make environmental information available. Currently the matters concerning right to environmental information are regulated in the new Act of 3 October 2008 on Access to Information on Environment and its Protection, Public Participation in Environmental Protection and on Environmental Impact Assessment (further referred to as the Act of 2008) ${ }^{6}$.

By means of the act the international law and the EU law acts, binding Poland in reference to those matters, are currently being implemented into the Polish law. In the first place, the United Nations Economic Commission for Europe (UNECE) Convention on Access to Information, Public Participation in Decision-making and Access to Justice in Environmental Matters ${ }^{7}$ should be pointed out. The Convention was signed by Poland on 25 June 1998 and ratified on 15 February 2002. In accordance with article 91 section 1 of the constitution of 1997 after promulgation thereof in the Journal of Laws of the Republic of Poland (Dziennik Ustaw), a ratified international agreement shall constitute part of the domestic legal order and shall be applied directly, unless its application depends on the enactment of a statute. The body competent to ratify international agreements is the President

4 Journal of Laws of 2000, No 109, item 1157 with amendments.

5 I.e. Journal of Laws of 2008, No 25, item 150 with amendments - Art. 19-24a and Art. 31-39; still binding; further referred to as the Environmental Protection Act.

6 Journal of Laws of 2008, No 199, item 1227 with amendments; further referred to as Act of 2008

7 Journal of Laws of 2003, No 78, item 706; the EU approved the Aarhus Convention on 17 February 2005 - see: Council Decision of 17 February 2005 on the conclusion, on behalf of the European Community, of the Convention on access to information, public participation in decision-making and access to justice in environmental matters (2005/370/ EC), OJ L 124, 17/05/2005, p. 1. 


\section{Right to access to environmental information in the Polish environmental..}

of the Republic of Poland. The constitution of 1997 divides ratified international agreements into two groups: agreements, to ratification of which the parliament's assent in the form of an act is necessary (these are, as a rule, agreements of significant responsibility for the state within the matters of the country's defences, taxes or human and citizen rights - as it is in case of the Aarhus convention) and agreements, which do not require such an assent to be ratified. In accordance with article 91 section 2 of the Constitution an international agreement ratified upon prior consent granted by statute shall have precedence over statutes if such an agreement cannot be reconciled with the provisions of such statutes.

The provisions of the Aarhus convention are divided into three pillars - the provisions regarding right to access to environmental information (pillar I), the provisions regarding public participation rule in environmental protection matters (pillar II) and the decisions obliging the consignors of the convention to ensure the access to justice in case of breach of those two rights (pillar III) ${ }^{8}$. Using the accepted in the Aarhus convention approach towards the issues of public participation will allow to present Polish legal solutions in the field in a better way. Taking into consideration the fact that the European Union is also the consignor of the Aarhus convention, Poland as a member state of the EU is obliged to implement the EU directives accomplishing the aims of the convention: directive 2001/42/ EC of the European Parliament and of the Council of 27 June 2001 on the assessment of the effects of certain plans and programmes on the environment ${ }^{9}$; directive 2003/4/EC of the European Parliament and of the Council of 28 January 2003 on public access to environmental information and repealing Council Directive 90/313/EEC ${ }^{10}$; directive 2003/35/ EC of the European Parliament and of the Council of 26 May 2003 providing for public participation in respect of the drawing up of certain plans and programmes relating to the environment and amending with regard to public participation and access to justice Council Directives 85/337/ EEC and 96/61/: $\mathrm{EC}^{11}$. The aim of the Act of 2008 is so the amending the

8 The Aarbus Convention: An Implementation Guide, prepared by S. Stec, S. CaseyLefkowitz with J. Jendroska, New York and Geneva, 2000, p. 5-6.

9 OJ L 197, 21/07/2001, p. 30.

10 OJ L 41, 14/02/2003, p. 26.

11 OJ L 156, 25/06/2003, p. 17. 
law on environmental information in a way consistent with the Aarhus convention and the EU law, as well.

\section{Subjective scope of the right to environmental information}

In accordance with article 4 of the Act of 2008 everybody has the right to information on environment and its protection under conditions laid down by the act. The conditions are indicated in section II of the act - Access to information on environment and its protection (articles 8-28). According to article 4 'everybody' has the right to environmental information, whereas 'everybody' means a natural person or a legal person and administrative bodies without legal personality (without corporate status). In case of a natural person, within the matters regarding right to environmental information, citizenship, age and capacity to perform acts in law should be taken into consideration.

The Constitution of 1997 as well as the Act of 2008, clearly indicate that the law serves 'everybody', i.e. Polish citizens as well as foreigners. As regards the age, according to the Polish law, a natural person obtains the full capacity to perform acts in law (i.e. capacity to take part in legal actions independently) at the age of 18 years. Children under the age of 13 years and persons over the age of 18 years declared legally incapacitated have no capacity to perform acts in law. Children ages 13 through 18 years and persons over the age of 18 years declared partially legally incapacitated have limited capacity to perform acts in law, i.e. the effectiveness of legal actions undertaken by those persons depends, as a rule, on the consent of their legal representatives (parents or guardians) ${ }^{12}$.

In jurisprudence it is indicated that in the case when it is necessary to submit a request initiating proceedings to obtain environmental information

12 K. Gruszecki, Komentarz do art. 4 ustawy z dnia 3 października 2008 r. o udostępnianiu informacji o środowisku i jego ochronie, udziale spoteczeństwa w ochronie środowiska oraz o ocenach oddziatywania na środowisko (Journal of Laws 08.199.1227), teza 4, in: K. Gruszecki, Komentarz do ustawy z dnia 3 października 2008 r. o udostępnianiu informacji o środowisku $i$ jego ochronie, udziale spoteczeństwa w ochronie środowiska oraz o ocenach oddziatywania na środowisko, LEX/el. 2009. 


\section{Right to access to environmental information in the Polish environmental..}

(passive access to environmental information), the applicant should have at least limited capacity to perform acts in law. Whereas in the case when a formal request is not required to obtain the information (active access to environmental information), the applicant does not need to have full capacity to perform acts in $\mathrm{law}^{13}$. The above issue has a particular significance regarding ecological education among children and adolescents under the age of 18 years, within which children and adolescents are encouraged to participate actively in various initiatives for environment and its protection. The opportunity to obtain exact environmental information certainly contributes to bigger participation of children and adolescents (especially ages 13 through 18) in this matter. However, the Act of 2008 and the act of 14 June 1960 the Code of Administrative Procedure ${ }^{14}$ do not give them the full opportunity.

The subjects responsible for providing environmental information, in accordance with article 8 of the act of 2008, are administrative bodies, who hold environmental information or to whom the information is directed. In accordance with the legal definition, presented in article 3 section 1 point 9 of the act of 2008, the notion administrative organ includes: ministers, central government administrative bodies, voivodes, other local government administrative bodies operating in voivodes' name or their own name and local government units. Moreover, other bodies will be qualified in the same way if they are appointed by virtue of law or on the grounds of agreements to conduct public tasks concerning environment and its protection. Analysing implemented by the legislator criterion holding environmental information to qualify bodies responsible in this matter, we should concur with the opinion that those are the bodies, who hold environmental information on account of their statutory duties. Therefore, only those bodies will be obliged to fulfil the right to environmental information of private subjects. Whereas administrative bodies, who do not collect and hold information on environment and its protection (e.g. tax authorities), will not have that obligation $^{15}$.

13 Ustawa - Prawo ochrony środowiska. Komentarz, ed. J. Jendrośka, Wrocław 2001, p. 148-149; I. Skrzydło-Niżnik, P. Dobosz, Prawne problemy procesu inwestycyjno-budowlanego $i$ konserwatorskiego, Kraków 2002, p. 245-246.

14 I.e. Journal of Laws of 2000, No 98, item 1071 with amendments.

15 J. Ciechanowicz-McLean, Z. Bukowski, B. Rakoczy, Prawo ochrony środowiska. Komentarz, Warszawa 2008, p. 76. 
Environmental care and protection are the tasks conducted in Poland by several public administrative bodies, governments' (national and local) and local governments' (at gmina, powiat and voivodeship level). The following bodies can be pointed out here: the Minister of Environment, the Environmental Protection Inspection bodies (the Chief Inspectorate and 16 voivodeships' environmental protection inspectorates), the environmental protection directors (the General Director and 16 local directors), the President of the National Water Management Authority and the presidents of local water management authorities, the marshals of the voivodeships, the marshals of the sejmiks, starosts and poviats' councils, heads of villages, mayors, presidents of cities and gminas' councils. Moreover, specialized administration: nature preservation administration (e.g. directors of national parks and the National Park Services), hydrological and meteorological services, hydro-geological services, marine, forestry, fishery, hunting and mining supervisory administration.

\section{Objective scope of the right to environmental information}

The objective scope of the right to environmental information is determined by a notion information on environment and its protection. In accordance with article 9 section 1 of the act of 2008 it is the information applying to:

1) state of environmental elements, such as: air, water, land surface, minerals, climate, landscapes and natural sites, including marshes, coastal and marine zones, plants, animals and mushrooms other elements of biological diversity, including genetically modified organisms and the interactions among these elements;

2) emissions, including radioactive waste and pollution, which impacts or might impact environmental elements, mentioned in point 1 ;

3) measures, such as: administrative and political measures, legal regulations regarding environment and water management, plans, programmes and agreements within environmental protection and actions, which impact or might impact environmental elements, mentioned in point 1 and emissions and pollution, mentioned in point 2, as well as measures and actions, which aim is to protect those elements; 


\section{Right to access to environmental information in the Polish environmental..}

4) reports on fulfilment of rules regarding environmental protection;

5) analyses of costs and benefits and other economic analyses and assumptions used within measures and actions, mentioned in point 3 ;

6) state of human health, safety and the living conditions of people, state of constructions and cultural heritage - in the scope, in which following elements impact or might impact them:

a) state of environmental elements, mentioned in point 1 , or

$\mathrm{b}$ by environmental elements, mentioned in point $1-$ emissions and pollution,

c) mentioned in point 2 , and measures, mentioned in point 3 .

By far the Polish administrative courts have not said much in their rulings based on art. 9 section 1 of the Act of 2008 and the definition of environmental information included in the act. The exception is the verdict of the Voivodship Administrative Court in Szczecin of 21 October $2010^{16}$, issued in the case between an administrative body - the marshal of the voivodeship and a joint-stock company. The company submitted the request to the marshal of the voivodeship to obtain the copies of reports regarding a chosen recycle organization with the list of entrepreneurs, in the name of whose the organization acted, and the copy of the overall statement presenting the fulfilment of recycling duties for an indicated period submitted to the Ministry of Environment. The marshal of the voivodeship did not handle the request, indicating that the report can not be made available based on article 9 section 1 of the Act of 2008, because this rule enumeratively lists the scope of information, which the administrative body has to make available. In the assessment of the marshal, the report presenting the list of companies is not included in the scope of information, which are mentioned in the rule. From the point of view of the Polish administrative proceedings law, such a situation (when the body does not handle the request positively and at the same time says that it can not issue a negative decision - in this case because the body accomplished that the data is not 'environmental information') is qualified as so called authority's idleness. On the other hand the joint-stock company, as an applicant, thought that the requested information is included in the category defined in article 9 section 1 point 4 of the Act of 2008 (i.e. a report on fulfilment of rules concerning environmental protection), in that case first the

16 Syg. II SAB/Sz 35/10, published: http://orzeczenia.nsa.gov.pl 


\section{Karolina Karpus}

company appealed the marshal to act and then submitted the complaint to the administrative court.

The Voivodship Administrative Court stated that, based on article 9 section 4 of the Act of 2008, the contentious issue was how to understand the word 'report', used by the Polish legislator in the rule, and above all whether a document called a 'statement' is comprised is the word 'report'. The Court presented its view on the matter in the verdict saying: in the content of the heretofore mentioned acts one will not find the legal definition of a report and a statement, which results that one should use in this matter definitions commonly used in the Polish language. Therefore the Court used the definitions from the Universal Dictionary of the Polish Language PWN (...), Warsaw 2008, p. 887 and p. 1350. According to this source, a report is an oral or written statement, notification about something, usually a supervisor, a superior institution, etc., an account or a dispatch. Whereas a statement is an oral or written presentation of a course of events, a detailed coverage of something, a description of events, incidents, an account or report. The comparison of those definitions leads to a conclusion that they bave common semantic characteristics and in the context of this matter they should be used interchangeably. As a result the Administrative Court took the complaint of the company into consideration and obliged the marshal of the voivodeship to act (i.e. make environmental information available).

It might seem that the lack of broader judicature of the Polish administrative courts on matters regarding right to environmental information arises rather due to a relatively little usage of the right within the passive environmental information. The above mentioned verdict confirms the assumption that solely the definition of 'environmental information' might be a contentious issue.

As regards the form of making environmental information available allowed by the Polish legislator, article 9 section 2 of the Act of 2008 defines that it can be revealed in an oral, written, visual, aural, electronic or any other form. The solution is consistent with article 2 section 3 of the Aarhus convention, which says that "Environmental information" means any information in written, visual, aural, electronic or any other material form. The Polish legislator in article 9 section 3 of the Act of 2008 indicates, as regards the information on environmental emissions, that public authorities are also obliged, on the request of the applicant, to attach information about the place, where the data on the methods of carrying out measurements is kept, including the methods of samples collection and 
Right to access to environmental information in the Polish environmental...

processing and about the methods of interpretation of obtained data used to produce the available information, or refers to applied methods in this matter.

The Polish act, similarly to the Aarhus convention and the EU law, regulates the issues of the right to information on environment and its protection on two levels: active and passive access to environmental information.

\section{Active access to environmental information}

The active access to environmental information is about data collecting and processing by an administrative body in order to make it available to public and about active data dissemination (e.g. by placing information on web pages, paper publications, issued announcements $)^{17}$. The Aarhus convention refers to this issue in article 5 (Collection and dissemination of environmental information) and the directive 2003/4 in the article 7 (Dissemination of environmental information). The Polish legislator placed the fundamental part of general rules regarding active access to environmental information and its protection in the act of 2008. However, the rules regarding the fundamental instrument used in the process were placed in the EPA. That instrument is the national environmental monitoring (NEM), which according to article 25 section 2 of the EPA, is the system of measurements, assessments and forecasts of the state of environment and collection, processing and dissemination of environmental information, providing public authorities and society with environmental knowledge. The authorities coordinating the system are the Inspections for Environmental Protection $^{18}$.

Within the national environmental monitoring data from different sources is collected. That includes: measurements done by administrative bodies, obliged on the grounds of the act to do environmental monitoring

17 J. Jendrośka, M. Bar, Prawo ochrony środowiska, Wrocław 2005, p. 119.

18 The inspections act on the grounds of the act of 20 July 1991 on the Inspection for Environmental Protection, i.e. Journal of Laws of 2007, No 44, item 287 with amendments, see Program państwowego monitoringu środowiska na lata 2010-2012, GIOŚ, Warszawa 2009, www.gios.gov.pl. 
research; data collected within public statistics, defined annually in research programmes of public statistics; information made available by other administrative bodies; measurements of the state of environment, amount and kinds of emissions, as well as records, to keeping of which the entities are obliged by law or decisions; other information, obtained for a fee or free of charge from entities that are not public administrative bodies. Concluding, on one hand, the system collects data obtained by public administration bodies and, on the other hand, data obtained by private entities.

Public administration bodies obtaining environmental information can be divided into bodies dealing directly with environmental protection (especially by doing own research on the state of environmental elements) and other public administration bodies, who obtain environmental information dealing with matters in other areas than environment. Whereas private entities transferring information for needs of the national environmental monitoring can be divided into entities obliged to do it by law and entities transferring information voluntarily. The obligation of transferring information also means transferring them free of charge. Subjective as well as objective scope of the national environmental monitoring shows how extensive the system is and how significant it is for active public access to information on the state of environment.

The Act of 2008 also indicates instruments of active access to environmental information in Poland other than the national environmental monitoring. One of them, worth mentioning, is the Public Information Bulletin, an official teleinformatic publication, which has a unified system of pages in a teleinformatic network ${ }^{19}$. The aim of the Bulletin is to disseminate information on public matters in Poland. In accordance with the Act of 2008, within the active access to environmental information, the Bulletin makes available: lists of documents containing environmental data, defined electronic data bases on environment and acts of law (documents) concerning environment.

The establishment of the obligation of making lists of documents containing environmental information in electronic version by administrative bodies and making them available by the Bulletin aims to fulfil the provisions of the Aarhus convention and the EU law. The lists should facilitate seeking acts and documents. In Poland placing data on an

19 See art. 8 of the act of 6 September 2001 on access to public information (i.e. Journal 
Right to access to environmental information in the Polish environmental...

act or a document in the list means shortening the period of making the act or the document available in the first place within the passive access to environmental information and secondly, in accordance with article 26 section 1 of the Act of 2008, the access to the act in the registered office of an administrative body is free of charge.

As regards the subjective scope of such lists of documents, the Polish legislator, in article 21 section 2 of the Act of 2008, enclosed the catalogue of data mentioned in publicly available lists (consisting of 36 points), constituting the minimum of duties of administrative bodies. Article 21 section 3 says that in publicly available lists, apart from the minimum, data on other documents regarding information on environment and its protection can be enclosed. In accordance with article 22 section 1 administrative bodies, competent in issues mentioned in the catalogue of data, are obliged to keep publicly available lists. In accordance with article 23 of the Act of 2008 publicly available lists are kept in an electronic form and an administrative body, obliged to keep the list, makes it available in the Bulletin. As regards the unification of rules of describing acts and documents mentioned in such lists, they were defined in the order of the Minister of the Environment of 22 September 2010 on the pattern as well as the content and layout of publicly available lists of data about documents including information on environment and its protection ${ }^{20}$.

The Polish legislator applied a similar method of regulation in case of electronic data bases made available by means of the Bulletin. It relies on enumerating in article 24 section 1 of the Act of 2008 types of information obtained on the grounds of the following acts: the EPA (on: air protection; assessment of the soil and ground; areas endangered by land mass movement and areas, where the movements appear; acoustic maps; areas endangered by noise and programmes of environmental protection against noise; assessment

20 Journal of Laws of 2010, No 186, item 1249, Pattern - publicly accessible list of data about documents including information about environment and its protection - Information card: 1. Card number / year; 2. Type of document; 3. Document topic; 4. Document name; 5. Subjective scope of document; 6 . Area, to which document refers, in accordance with the administrative division of the country; 7. Case signature; 8 . Document made by; 9 . Date of document; 10. Document approved by; 11. Date of document approval; 12 . Place of document storage; 13. Electronic Address including reference to document; 14. Is the document final yes/no; 15. Card numbers of other documents in the case; 16. Date mentioned in the list of data about document; 17. Stipulations regarding lack of access to information; 18. Comments. 
of electromagnetic field levels; areas, where acceptable electromagnetic field levels were exceeded; seasonal level measurements of substances or energy introduced in relation with exploitation of a road, tram line, airport or harbour; emissions and consumption of water), the Act on Waste of 27 April $2001^{21}$ (on data regarding waste production and management, as well as providing permits within waste production and management) and the Water Law act of 18 July $2001^{22}$ (on information about the state of surface and underground waters). Among the bodies keeping electronic databases, according to article 24 section 3 of the Act of 2008, there are: the marshal of the voivodeship, starost, voivodeship environmental protection inspector, entity in charge of a road, railway, tram line, airport or harbour. The order of the Minister of Environment of 23 November 2010 on the method and frequency of environmental information updating ${ }^{23}$ defines in detail the way of making information available in such electronic databases, the minimal scope and form of available information, as well as the frequency of their updating.

\section{Passive access to environmental information}

The passive access to environmental information relies on conveying it by an administrative body on the request of an applicant ${ }^{24}$. Those matters are regulated in article 4 of the Aarhus convention (Access to environmental information) and in articles 3-4 of the directive 2003/4 (Access to environmental information upon request; Exceptions). In the Polish act of 2008 the passive access to information on environment and its protection is mentioned in articles 13-20. The request to obtain information has as a rule a written form, however, in article 12 section 2 of the Act of 2008, the Polish legislator indicated that some information is available without a written request, i.e. in the first place information, which does not require searching and secondly in case of a natural disaster, technical failure or any other direct danger to human life or environment, caused by human

21 I.e. Journal of Laws of 2010, No 185, item 1243 with amendments.

22 I.e. Journal of Laws of 2005, No 239, item 2019 with amendments.

23 Journal of Laws of 2010, No 227, item 1485 with amendments. 
Right to access to environmental information in the Polish environmental..

activity or natural causes. That is information held by administrative bodies or intended for them, enabling persons, who could suffer due to the threat, to undertake actions to prevent or minimise damages resulting from such threats.

K. Gruszeczki criticises the solution implemented by the Polish legislator in article 12 of the Act of 2008 as not compliant with article 63 section 1 of the act of 14 June 1969 the Administrative Proceedings Code (further referred to as the Code) ${ }^{25}$. In accordance with the Code, requests (demands, explanations, appeals, complaints) directed to public administration bodies in Poland may be submitted in a written form, by telegraph, telefax or orally, as well as by other means of electronic communication by electronic mailbox of a public administration body, established on the grounds of the act of 17 February 2005 on IT implementation of activities of entities conducting public tasks ${ }^{26}$. There are no arguments, which could explain, why in the case of a request to obtain environmental information, the form was narrowed to a written form, completely omitting the issue of electronic communication means. From the current article 12 of the Act of 2008 one may conclude that the Polish legislator deliberately narrowed the solution regarding the request, which diverges from the trend, present in the Polish administrative law for a long time, of using electronic communication means ${ }^{27}$.

The Polish legislator in article 13 of the Act of 2008 explicitly indicated that the applicant requesting information on environment and its protection does not need to show legal or actual interest, satisfying the provisions of the Aarhus convention, as well as the directive 2003/4. As regards the time limit of handling the case it is the same as in those two acts. In article 14 section 1-2 of the Act of 2008 it was indicated that an administrative body makes information on environment and its protection available (or refuses the access) as a rule as soon as possible and at the latest within one month after the request has been submitted. The period may be extended up to two months due to the complexity of the case. The access to documents which are published in publicly available lists, as well as the access to

25 I.e. Journal of Laws of 2000, No 98, item 1071 with amendments; further referred to as the Code.

26 Journal of Laws of 2005, No 64, item 565 with amendments.

27 K. Gruszecki, Ustawa o udostępnianiu informacji o środowisku i jego ochronie, udziale spoteczeństwa w ochronie środowiska oraz o ocenach oddziatywania na środowisko. Komentarz, Warszawa 2009, p. 49-50. 
documents enabling to undertake actions in order to prevent or minimise harm of damage on account of natural disaster, other disaster or technical failure or any other danger to human health or environment, caused by human activity or natural causes were treated in a special way as regards the period of handling the case. In such situations the case is dealt with on the day of submitting the request.

The request to obtain environmental information submitted by the applicant should fulfil general demands in accordance with article 63 section 2 of the Code, which says that each application to a public administration body should include at least the name of the person, who submits the motion, their address and their demand and it should satisfy any other demands settled in the specific rules. The example of such a specific rule is article 15 section 1 of the Act of 2008 predicting that the access to information on environment and its protection occurs in the mode and the form specified in the request. One may assume, that the Polish legislator encourages in this way applicants submitting requests to choose the form of obtaining requested information. In a situation, when the form of requested information on environment and its protection is specified and the body is not able to fulfil the demand because it does not possess right technical means, then according to article 15 section 2 of the Act of 2008, the body is obliged to inform the applicant in a written form within 14 days from the day of submitting the request about the reasons for lack of possibility of obtaining information in accordance with their request, indicating at the same time how and in which form the information may be obtained. Within the 14-day period the applicant should submit the request in a mode and a form specified in the notification. If they do not do that, then the administrative body issues a decision refusing the access to information in the mode and the form specified in the request.

The above collision rules are helpful in settling the difficulties connected with the objective impossibility of receiving environmental information in a form requested by an applicant. However, there are no collision rules in the Act of 2008 specifying what an administrative body should do in a situation when an applicant does not specify the mode and the form of a requested information. It seems that such a situation may be qualified as so called formal deficiency of the request, which allows to refer to general rules of the Code. It specifically refers to article 64 of the Code, which says that if an applicant does not include their address in a request and there is no possibility to determine this address on the grounds of possessed data, 
Right to access to environmental information in the Polish environmental..

the request is not examined. And if the request does not satisfy any other demands specified in the rules, then an applicant should be summoned to remove deficiencies in the period of seven days with an instruction that if they do not remove the deficiencies then the request will not be examined. From the point of view of an applicant such a solution seems to to be safer then assumption that if the request does not specify the mode or the form of the access to information then the body may decide alone how to handle the request.

In article 19 section 2 of the Act of 2008 the Polish legislator took into consideration the situation when an applicant submits the request to access information on environment and its protection to a wrong administrative body, which in that situation means the body who does not hold requested information or for whom requested information is not intended ${ }^{28}$. According to this rule if the body does not hold requested information, the body as soon as possible and at the latest within 14 days from the date of submitting the request: 1 ) conveys the request to the administrative body who holds requested information, and notifies the applicant about it; it is reserved that the application submitted to a wrong body before the expiry of the time limit is considered to be submitted retaining the time limit; 2) returns the request to the applicant if it is not possible to find an administrative body who holds requested information.

The positive handling of the request to access information on environment and its protection by the right body occurs by so called substantive technical action, whereas the refusal of access to requested information occurs as an administrative decision. 'A substantive technical action' is a kind of so called actual actions, which are next to so called legal actions, a form of public administration bodies' activities in Poland. In the Polish administrative law, the defining of 'actual activity' is very difficult. According to M. Wierzbowski and A. Wiktorowska, who made an attempt to define it, the difference between legal actions and actual actions relies on the fact that legal actions result in defined proceedings norm [rule]. (...) Whereas actual actions may form legal interactions through facts and not through proceedings

${ }^{28}$ In accordance with art. 3 section 2 of the Act of 2008, 'information intended for an administrative body' is information in hands of the third person on behalf of an administrative body, including information the body has the right to demand from the third person; and according to article 3 section 3 'information kept by an administrative body' is information obtained by the body or from the third person. 
rules. In the assessment of the two authors so called substantive technical actions are those actions of administrative bodies, which being actual actions, are based on a clear legal base and cause real legal results. (...) However, substantive technical actions are neither administrative nor normative acts (...). They differ from them [from both kinds of acts] in the way that they occur as real events ${ }^{29}$. In the case of positive handling of the request to access environmental information the action relies on making requested information available by the body in a written form or on a specified data carrier.

In articles 16-20 of the Act of 2008, the Polish legislator regulated the issue regarding the grounds of refusal to access information on environment and its protection, occurring as it is said above, in a form of an administrative decision. The Polish legislator predicted in this case a decision, as this document ensures proper legal protection of the applicant submitting the request. It comes here to combination of the issues from pillar I and pillar III of the Aarhus convention - i.e. ensuring the access to justice in case of refusal to fulfil the law from pillar I. In accordance with the Polish administrative proceedings Code, the applicant has the right to 'appeal' from the decision, which the applicant submits within 14 days from the delivery or announcement of the decision. A body of first instance conveys then the appeal together with case files to a body of second instance. The applicant can file an administrative complaint to a decision of a body of second instance, which is confirmed in article 20 section 2 of the Act of 2008 in the case of refusal the access to information on environment and its protection. To assure faster proceedings of an administrative court in the case of a complaint to the decision refusing access to environmental information, the Polish legislator shortened the usual time limit, which results in conveying case files by a body of second instance and a reply to a complaint within 15 days from the day of obtaining the complaint. The administrative court examines the complaint within 30 days from the day of obtaining the files together with the reply to the complaint. The appeal of the sentence of the voivodeship administrative court can be submitted to the Chief Administrative Court in Warsaw.

The grounds for refusal to release environmental information were divided by the Polish legislator in the Act of 2008 into two groups - obligatory and optional grounds for refusal. The obligatory grounds were included in article

29 M. Wierzbicki, A. Wiktorowska, Prawne formy dziatania admnistracji, in: Prawo administracyjne, ed. M. Wierzbowski, Warszawa 2009, p. 294-296. 
Right to access to environmental information in the Polish environmental...

16 of the Act of 2008, on the grounds of which an administrative body does not make information on environment and its protection available if the information applies to:

1) individual data obtained in statistical research of public statistics protected by statistical secret, which is mentioned in the act of 29 June 1995 on public statistics ${ }^{30}$

2) pending cases in judicial, disciplinary or penal proceedings if the release of information could disturb the proceeding;

3) issues being subject of copyrights, which are mentioned in the act of 4 February 1994 on copyrights and related rights ${ }^{31}$, or patent rights, mentioned in the act of 30 June 2000 on industrial property law ${ }^{32}$, if the access to information could breach the rights;

4) personal data, mentioned in the act of 29 August of 1997 on personal data protection ${ }^{33}$, applying to third persons if the access to information could breach the laws on personal data protection;

5) documents or data delivered by third persons if the persons delivered them voluntarily and submitted stipulation of not making the information available, although the persons were not obliged to deliver them and they can not be given the obligation to do it;

6) documents or data, which made available could cause danger to environment and to ecological safety of a state;

7) information on trade value, including technological data, delivered by third persons and being the company's secret if the access to information could deteriorate the competitive position of those persons and they submitted justified motion to exclude the right to access information;

8) undertakings, which could significantly impact environment, conducted in confined spaces, which are not under investigation with society participation, according to article 79 section 2 ;

9) state defence and security;

10) public security.

In reference to the premise concerning the refusal to access environmental information on account of the protection of company's

30 Journal of Laws of 1995, No 88, item 439 with amendments.

31 I.e. Journal of Laws of 2006, No 90, item 631 with amendments.

32 I.e. Journal of Laws of 2003, No 119, item 1117 with amendments.

33 I.e. Journal of Laws of 2002, No 101, item 926 with amendments. 
secret, the Polish legislator maintained that the use of the information depends on a prior motion of the entity, who was obliged to submit such data. There is a conflict of two private interests here - on one hand the right to environmental information of the entity submitting request to obtain it and on the other hand the protection of company's secret of an individual entity, who was obliged to submit such data to right bodies on account of informing on environment. In the assessment of the Polish legislator, the solution to this conflict should depend on the initiative of the entity seeking the protection of company's secret. The entity has to submit a justified request to exclude such information from the right to access environmental information. An administrative body examines the request and its positive handling occurs by way of substantive technical actions (exclusion from making some data available), whereas according to article 16 section 2 of the Act of 2008 the refusal to examine the request to exclude information from making it available on account of the protection of company's secret occurs as an administrative decision ${ }^{34}$. That solution is definitely more rigorous in comparison to stipulations submitted by third persons, who voluntarily submit environmental information (article 16 section 5 of the Act of 2008), which are not assessed by a public administration body.

Furthermore, in case of environmental information, indicated in article 16 section 1 point 1 and points $4-8$ of the Act of 2008, i.e. including data under statistical protection, personal data protection or the protection of company's secret, as well as data voluntarily submitted by third persons; data, which release would endanger environment or ecological safety of a state; or data on undertakings in confined spaces - they will be released to the applicant, although they were initially qualified as obligatory premises to refuse the access to environmental information if at the same time they refer to: 1) amount and type of dusts and gases introduced into the air and locations of introduction; 2) state, composition and amount of sewage introduced into water or ground and locations of introduction; 3) type and amount of produced waste and locations of production; 4) level of emitted noise; 5) level of emitted electromagnetic fields.

In the group of optional grounds to refuse access to environmental information, the Polish legislator indicated in article 17 of the Act of 2008 the following premises:

34 K. Gruszecki, Ustawa o udostepnianiu..., p. 66-67. 


\section{Right to access to environmental information in the Polish environmental..}

1) access to environmental information would request submitting documents or data in the course of work;

2) access to environmental information would request submitting documents or data intended for internal communication;

3) request to obtain environmental information is impossible to handle in obvious way;

4) request to obtain environmental information is formulated in a too general way.

In the case of two above mentioned optional grounds to refuse the access to environmental information, the Polish legislator additionally defines duties of an administrative body. In accordance with article 19 section 1 of the Act of 2008 an administrative body, who refuses to make environmental information available on account of that it would demand to deliver documents or data being in the course of work, the body gives at the same time the name of the body responsible for elaboration of such a document or data and informs about the time period of the elaboration. Whereas, according to article 19 section 3 of the Act of 2008, if the request is formulated in a too general way, an administrative body as soon as possible and at the latest within 14 days after receiving the request, call an applicant to complete the request, giving appropriate explanations, especially informing about the possibility to use publicly available lists. The summon in the case of a too general request should serve to strengthen the right to environmental information, however, completion of the request does not exclude the possibility to refuse the access to environmental information on the grounds of that optional ground.

The provisions of the Act of 2008 regarding the fees in case of access to environmental information (articles 26-28) are consistent with the provisions of the Aarhus convention and the directive 2003/4. In accordance with article 26 section 1 of the Act of 2008, searching and seeing documents listed in a publicly accessible list in the registered office of an administrative body is free of charge. Whereas, in accordance with article 26 section 2 of the Act of 2008, for searching information, as well as conveying it in a form indicated in the request, copying documents or data and sending them, an administrative body takes charges in the amount reflecting the costs connected with it. Maximum individual charges were defined by the Polish legislator in article 27 section 1 of the Act of 2008 and they are as follows: for searching information up to ten documents - PLN 10; the charge rises not more than PLN 1 for every next document if information requires more 


\section{Karolina Karpus}

than ten documents; for transforming information into a form indicated in the motion - PLN 3 for each electronic data carrier; for copying documents or data in A4 form: for black and white copy - PLN 0.60, for colourful copy - PLN 6.

\section{Conclusion}

The Polish legal regulations regarding the right to environmental information, compiled currently in the Act of 2008, are to a large extent compliant with the acts, such as the Aarhus convention and the directive 2003/4. It applies to subjective and objective scope of the right, as well as ensuring the right to justice in case of refusal of releasing requested environmental information. The situation is similar as regards the instruments used within the active access to environmental information and the solutions implemented within the passive access to environmental information. The effort of the Polish legislator is noticeable, whose aim is to adjust the solutions resulting from the Aarhus convention and the EU law to the Polish administrative law, especially to administrative proceedings rules. As the task is not easy, in several matters the Polish legislator did not manage to omit mistakes, as in the case of omitting electronic means of communication in case of obtaining environmental information.

Taking into consideration the fact that in the Polish law system there is a similar law - right to public information, the Polish legislator within the regulations concerning right to environmental information uses the solutions implemented on the grounds of the first law (e.g. if it concerns the application to access information: positively - by means of substantive technical actions, negatively - by means of an administrative decision). Comparing both rights, one may expect that within the right to environmental information, together with increasing public knowledge about that legal instrument, the number of administrative courts' rulings within those matters will increase. 